\title{
Expression Profiles of 22 Novel Molecular Markers for Organogenetic Pathways Acting in Alfalfa Nodule Development
}

\author{
José I. Jiménez-Zurdo, ${ }^{1}$ Florian Frugier, ${ }^{1}$ Martín D. Crespi, ${ }^{1}$ and Adam Kondorosi ${ }^{1,2}$ \\ ${ }^{1}$ Institut des Sciences Végétales, Centre National de la Recherche Scientifique, F-91198 Gif-sur-Yvette \\ Cedex, France; ' Institute of Genetics, Biological Research Center, Hungarian Academy of Sciences, \\ Szeged, PO Box 521, H-6701 Szeged, Hungary \\ Accepted 1 October 1999.
}

During symbiotic nodule development, a variety of molecular signals of rhizobia and plant origin are likely to be involved in the control of the expression of specific genes in the legume Medicago sativa (alfalfa). Twenty-two new, nodule-associated expressed sequence tags (ESTs, MsNod clones) as well as $\mathbf{1 6}$ clones for previously reported alfalfa nodulins were identified by cold-plaque screening. Protein homologs were found for 10 of the 22 MsNod-encoded polypeptides, revealing putative novel functions associated with this symbiosis. Expression of these MsNod genes was investigated in spontaneous nodules (generated in the absence of bacteria), in nodules induced by a Sinorhizobium meliloti wild-type strain and $\mathrm{Eps}^{-}$and $\mathrm{Bac}^{-}$mutant derivatives, as well as in roots inoculated with a Nod $^{-}$mutant strain. This analysis enabled us to correlate plant gene expression with the different stages of nodule ontogeny and invasion. The effect of phytohormones on MsNod gene expression was analyzed in cytokinin- and auxin-treated alfalfa roots. Cytokinin induced the accumulation of seven MsNod transcripts, four of them were also regulated by the synthetic auxin 2,4-D (2,4-dichlorophenoxyacetic acid). Comparison of $\mathrm{MsNod}$ expression profiles in wild-type and transgenic $M$. truncatula roots overexpressing the early nodulin Enod40 suggested that one clone, the $M$. sativa L3 ribosomal protein homolog (MsNod377), is a putative component of an Enod40-dependent pathway acting during nodule development. These novel molecular markers may help in the investigation of gene networks and regulatory circuits controlling nodule organogenesis.

Under nitrogen limitation, soil rhizobia are able to induce the formation of nitrogen-fixing root nodules on their legumi-

Corresponding author: Martín D. Crespi; Telephone: +33-1-698 23703; Fax: +33-1-698 23695; E-mail: Martin.Crespi@isv.cnrs-gif.fr

Present address of José I. Jiménez-Zurdo: Departamento de Microbiología del Suelo y Sistemas Simbióticos, Estación Experimental del Zaidín, Consejo Superior de Investigaciones Científicas, Profesor Albareda 1, 18008 Granada, Spain.

Nucleotide and/or amino acid sequence data can be found at the GenBank and EMBL data bases under accession nos. AJ248318 to AJ2248341. nous plant hosts. This organogenetic process is triggered by a complex exchange of molecular signals that coordinate the spatio-temporal expression of specific genes in both symbionts (reviewed by Schultze and Kondorosi 1998). However, in the absence of rhizobia, certain Medicago sativa (alfalfa) cultivars ( $\mathrm{Nar}^{+}$phenotype) have the capacity to form nodulelike structures spontaneously when deprived of combined nitrogen. This suggests that nodule development elicited by bacterial signals is mainly controlled by the plant genome (Truchet et al. 1989).

Flavonoids present in root exudates are the main inducers of the bacterial nodulation (nod) genes, whose protein products are responsible for the biosynthesis and excretion of lipochitooligosaccharide signal molecules, the Nod factors. These signals are able to elicit developmental responses in roots, e.g., root hair deformation, preinfection thread formation, and division of cortical cells leading to the generation of the nodule primordia (Dénarié et al. 1996). However, formation of functional symbiotic nodules requires bacterial invasion, release, and differentiation into nitrogen-fixing bacteroids. In this regard, it has been shown that cell surface components like exopolysaccharides (EPS), lipopolysaccharides (LPS), and capsular polysaccharides (KPS) are major requirements for successful nodule invasion (see Becker and Pühler 1998; Kannenberg et al. 1998 and references therein). For the plant partner, the physiological state of the roots and the action of plant growth regulators are important factors determining competence for nodulation (Caetano-Anollés and Gresshoff 1991), which also requires nitrogen-limiting conditions and high photosynthetic activity. Opposing gradients of auxins, cytokinins, ethylene, and uridine (the stele factor; Smit et al. 1995) have been suggested to control position of cortical cell division foci (Libbenga et al. 1973). There is evidence that the mitotic activation of the root cortical cells is a consequence of phytohormonal imbalances induced in this tissue by Nod factor action, suggesting that plant hormones, mainly cytokinins and Nod factors, share elements in their signal transduction pathways leading to nodule formation (Hirsch et al. 1989; Cooper and Long 1994; Hirsch and Fang 1994; Bauer et al. 1996).

Plant genes specifically induced during nodule ontogeny and maturation of the nitrogen-fixing nodules (respectively, early and late nodulin genes) are direct or indirect targets of 
the different signal transduction cascades acting during this developmental program and can be used as molecular markers to dissect this process. The functions of the majority of the reported early nodulin genes have been proposed mainly on the basis of their expression patterns and their correlation with different symbiotic events such as preinfection (Mtripl, Cook et al. 1995), infection (Enod5, Enod12, Scheres et al. 1990a, 1990b; ENOD-GRPs, Schröder et al. 1997) and nodule meristem initiation or nodule structure formation (Enod2, Franssen et al. 1987; Enod40, Asad et al. 1994; Crespi et al. 1994; Matvienko et al. 1994). Among them, Enod40 is one of the first molecular markers expressed at the onset of nodule organogenesis in the root pericycle and cortex (Kouchi and Hata 1993; Yang et al. 1993; Crespi et al. 1994). Moreover, transgenic approaches suggest that Enod40 might be one of the elements involved in the induction of de-differentiation and division of cortical cells (Charon et al. 1997). Thus, Enod40 has been proposed as one of the key regulatory genes involved in a signal transduction pathway activated during nodule initiation.

Transcripts corresponding to putative nodulin genes have been identified by comparing mRNA populations of root and nodule tissues by differential screening, subtractive hybridization, and differential display reverse transcription-polymerase chain reaction (DD-RT-PCR) approaches (Kouchi and Hata 1993; Goormachtig et al. 1995; Gamas et al. 1996; Szczyglowski et al. 1997). We have recently developed an alternative procedure, so-called "cold-plaque screening" (Frugier et al. 1998), that has been successfully applied to the identification of novel transcripts expressed at medium or low level during the organogenesis of spontaneous nodules in the absence of bacteria. Notably, three genes coding for putative regulatory proteins were identified: a Wilm's tumor suppressor homolog, a protein kinase, and a zinc-finger protein (Frugier et al. 1998). We report here that, with this experimental approach, we have isolated a new group of genes differentially expressed during the organogenesis of $M$. sativa nodules upon Sinorhizobium meliloti infection. The expression profiles of these and a number of previously identified molecular markers of nodulation were investigated in roots, $\mathrm{Nar}^{+}$ nodules, and nodules arrested at different developmental stages by means of infection with several symbiotic mutants of $S$. meliloti. In addition, transcript levels of these genes were compared in Medicago spp. roots treated with phytohormones as well as those overexpressing the early nodulin gene MtEnod40 (Charon et al. 1997). Our results suggest the participation of the identified genes in different signal transduction pathways acting during nodule organogenesis and rhizobial invasion. Moreover, one putative component of an Enod40-dependent signal transduction pathway has been identified.

\section{RESULTS}

\section{Identification of novel differentially expressed transcripts in symbiotic alfalfa nodules.}

A young nodule $M$. sativa cDNA library was screened to identify a novel set of putative early nodulin genes following a cold-plaque based strategy (Frugier et al. 1998) as depicted in Figure 1A. cDNAs from developing nodules harvested 5 days after root infection with the wild-type strain Sm41 and from roots inoculated with the $\mathrm{Nod}^{-}$mutant derivative ZB138 were used as differential probes throughout the procedure. A thousand cold-plaque clones (i.e., phage lysis plaques showing no or faint hybridization signal to either of the probes) were randomly selected and subjected to two additional successive secondary screening steps based on PCR amplification of the phage inserts. This led to the identification of $37 \mathrm{cDNAs}$ whose expression was induced or enhanced in nodule tissues and one cDNA clone that was repressed during nodulation. Twenty-two of these cDNAs represent novel $M$. sativa expressed sequence tags (ESTs) associated with nodule development (MsNod clones).

The expression of a representative group of the selected clones was analyzed by Northern (RNA) blot (Fig. 1B) with total RNAs from control roots inoculated with the $\mathrm{Nod}^{-} \mathrm{mu}-$ tant strain and from young and mature symbiotic nodules, collected 5 and 14 days post infection with the wild-type Sm41, respectively. Differential expression of all the clones tested in this analysis was confirmed, thus validating the use of complex cDNA probes as a reliable tool for the serial analysis of gene expression.

\section{Sequence analysis of $\mathrm{Ms} \boldsymbol{N o d}$ clones.}

From the $5^{\prime}$ end of the isolated 38 cDNAs, sequences of 250 to 400 nucleotides were initially determined with the PCR products of the phage inserts as templates. Subsequent homology searches revealed that 20 corresponded to coding sequences already reported as nodulins in legumes; 16 of these were already identified in $M$. sativa, e.g., members of the leghemoglobin gene family (9 clones), Enod40 (2 clones), Enod25 (2 clones), EnodGRP5 (2 clones), the L3 ribosomal protein homolog (Mscp7, Frugier et al. 1998), and four clones exhibited similarities to nodulin sequences of other leguminous plants. In addition, six cDNAs showed significant homology to known proteins not found so far in nodule libraries; and the remaining 12 clones had no matches to any coding sequences in public data bases.

The full sequences of inserts representing novel $M$. sativa cDNAs (22 clones) were determined and deposited in the GenBank and EMBL data bases under accession numbers AJ248318 to AJ2248341. Significant homologies found for these clones at the protein level are listed in Table 1. Four of the $10 \mathrm{MsNod}$ clones with homologs in data bases are most likely full-length cDNAs, as deduced from the corresponding protein alignments.

Two cDNAs, MsNod20 and MsNod647, putatively code for M. sativa homologs of the soybean nodulin GmNod26 (Miao and Verma 1993) and early nodulin GmEnod93 (Kouchi and Hata 1993), respectively. The first one is a major peribacteroid membrane protein acting specifically in soybean root nodules whereas no function can be predicted for GmEnod93 on the basis of the homology search. MsNod202 transcript codes for a 127-residue-long polypeptide homolog to a cucumber basic protein (Murata at al. 1982). In addition, weak homology was found between this protein and the early nodulins GmEnod315 (Kouchi and Hata 1993), GmEnod55-2 (de Blank et al. 1993), and MtEnod16 (Greene et al. 1998), a group of proteins exhibiting traits in common with the family of phytocyanin-related proteins. Faint homology was also found between the MsNod648 transcript and the nodulin MtN29 (Gamas et al. 1996). 
The remaining six clones that exhibited homology to known genes have not been associated yet with nitrogen-fixing symbiosis. The deduced amino acid sequence of MsNod800 shows similarity with a number of known sugar transporters of different plant species, including the model legume $M$. truncatula (Harrison 1996). The highest level of identity was to a monosaccharide transporter of Petunia hybrida. The translated sequence of MsNod605 displays features of small proteins (97 to 112 residues) of unknown function encoded by the gibberellin-regulated GASA gene family identified in Arabidopsis thaliana and tomato (Shi et al. 1992; Herzog et al. 1995; Aubert et al. 1998). The putative MsNod658encoded protein shows strong homology to the higher plant Atriplex nummularia polypeptide ANJ1, which is homologous to the DnaJ heat shock protein that functions as a molecular chaperone in Escherichia coli (Zhu et al. 1993). MsNod398 putatively codes for a protein containing a domain of DNAbinding proteins belonging to the High Mobility Group 1 (HMG1) (data not shown). Although no function can be inferred for the MsNod660-encoded putative protein, it exhibits significant homology to a tomato polypeptide induced by

A

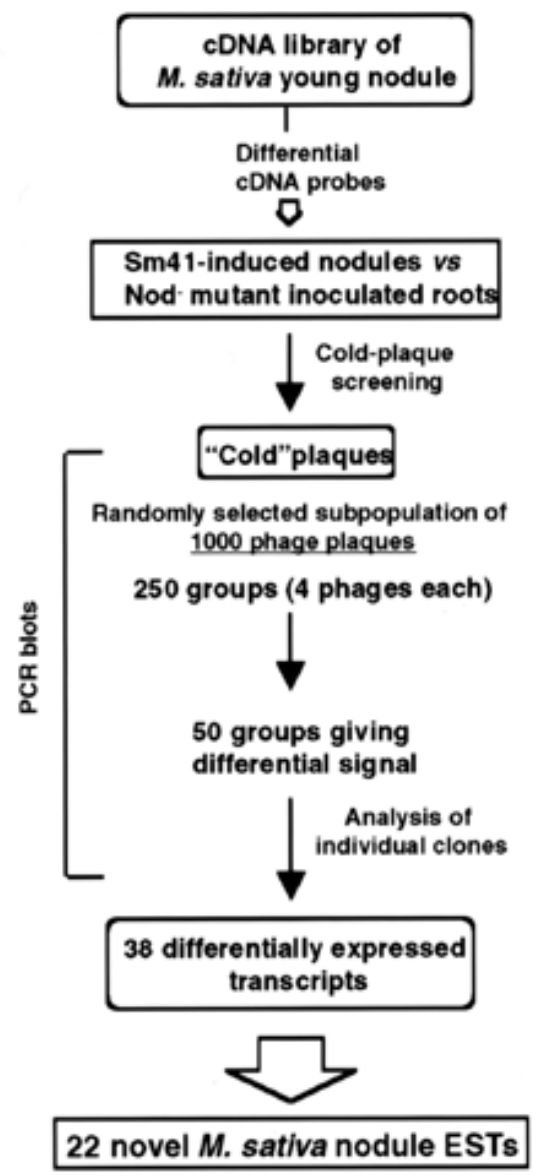

wounding. Finally, the Msc191 transcript that is repressed during rhizobial invasion codes for an $O$-methyl-transferase, a member of a group of enzymes acting on specific substrates throughout the lignin biosynthetic pathway (Inoue et al. 1998; Lee et al. 1998).

In summary, on the basis of sequence homologies, several putative novel functions can be predicted for genes acting during nodulation, thus providing the first clues for further functional studies in vivo.

\section{Organ specificity of $\mathrm{Ms}$ Nod gene expression.}

The prevalent criteria for a protein to be defined as a nodulin is its specific nodule location and induction during rhizobial infection (Legocki and Verma 1980; Franssen et al. 1992). Thus, in a first series of analysis, the organ-specific expression of a group of MsNod genes was addressed. Several filter sets were prepared, each containing a total of 28 PCR fragments from MsNod clones identified in our screening (24 clones) as well as from the Krüppel-like zinc-finger homolog Mscp17 (renamed MsZpt2-1; Frugier et al. 1998) and the MsEnod40 genes. Msc27 and a clone representing the leghe-
B

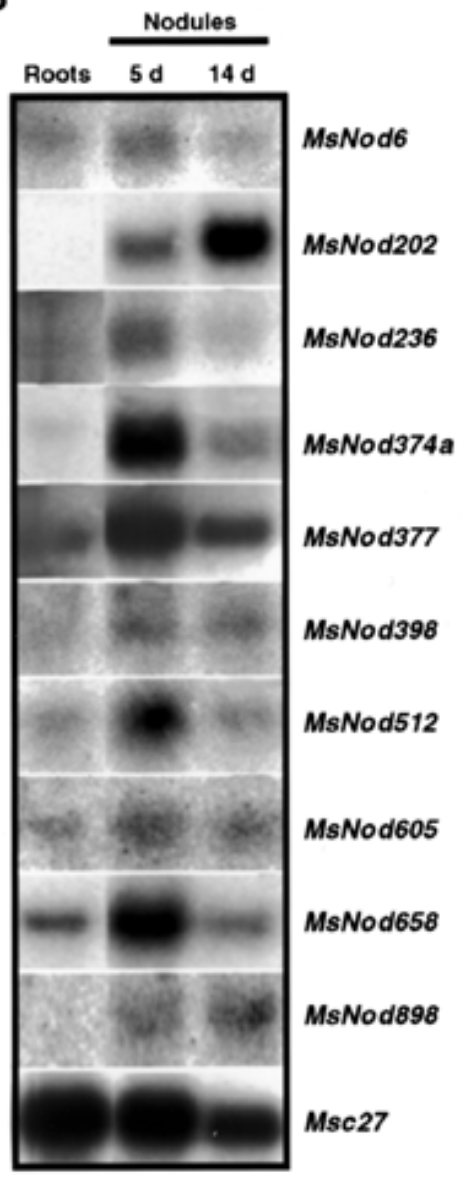

Fig. 1. Identification of new, differentially expressed transcripts in developing alfalfa nodules induced by Sinorhizobium meliloti. A, Cold-plaque screening strategy (for further details see Frugier et al. 1998). Blots of amplified phage inserts corresponding to 1,000 randomly selected cold-plaque clones were hybridized to 5-day-old, Sm41-induced nodules versus root cDNA probes to select individual, differentially expressed transcripts (MsNod clones). B, Northern (RNA) analysis of representative MsNod clones. Total RNAs (10 $\mu \mathrm{g})$ were obtained from nodules collected 5 and 14 days post infection with the wild-type strain Sm41 and roots inoculated with the Nod ${ }^{-}$mutant derivative ZB138. Probes used are indicated. Control of RNA loading and transfer was done by probing with $M s c 27$. 
moglobin gene family were included in each filter as constitutive and nodule-induced expression controls, respectively. cDNA probes derived from roots, stems, leaves, flowers, and symbiotic alfalfa nodules were prepared and used to hybridize to the filters. As summarized in Table 1, approximately 50\% of the clones analyzed displayed a hybridization signal that was detectable only in the nodule samples. This group of clones includes $M$. sativa homologs of already reported nodulin genes (MsNod20, MsNod647, MsNod648). Although the nodule-enhanced expression was confirmed in this experiment for the rest of the clones, varying levels of transcript accumulation were detected in roots and other non-symbiotic

Table 1. Primary characterization of MsNod clones, and sequence homologies and organ expression profiles

\begin{tabular}{|c|c|c|c|c|c|c|}
\hline \multirow[b]{2}{*}{ Clone } & \multirow{2}{*}{$\begin{array}{l}\text { Best homology } \\
\text { (statistical significance) }^{\mathrm{a}}\end{array}$} & \multicolumn{5}{|c|}{$\begin{array}{l}\text { Organ expression } \\
\text { profile }^{\mathbf{b}}\end{array}$} \\
\hline & & $\mathbf{N}$ & $\mathbf{R}$ & $\mathbf{S}$ & $\mathbf{L}$ & $\mathbf{F}$ \\
\hline \multicolumn{7}{|c|}{ Nodule-specific transcripts } \\
\hline MsNod2O & $\begin{array}{l}\text { Glycine max GmNod26 } \\
\quad\left(9,7 \cdot 10^{-76}\right)\end{array}$ & + & - & - & - & - \\
\hline MsNod647 & G. max GmEnod $93\left(9,7 \cdot 10^{-96}\right)$ & + & - & - & - & - \\
\hline MsNod648 & $\begin{array}{l}\text { M. truncatula } \mathrm{MtN} 29 \\
\quad\left(5,8 \cdot 10^{-2}\right)\end{array}$ & + & - & - & - & - \\
\hline MsNod135 & - & + & - & - & - & - \\
\hline MsNod 236 & - & + & - & - & - & - \\
\hline MsNod374a & - & + & - & - & - & - \\
\hline MsNod374b & - & + & - & - & - & - \\
\hline MsNod512 & - & + & - & - & - & - \\
\hline MsNod559 & - & + & - & - & - & - \\
\hline MsNod607 & - & + & - & - & - & - \\
\hline MsNod $660^{\mathrm{c}}$ & $\begin{array}{l}\text { Wound-induced protein } \\
\qquad\left(5,1 \cdot 10^{-27}\right)\end{array}$ & + & - & - & - & - \\
\hline MsNod898 & - & + & - & - & - & - \\
\hline MsNod 940 & - & + & - & - & - & - \\
\hline \multicolumn{7}{|c|}{ Transcripts detected in other plant organs } \\
\hline MsNod800 & $\begin{array}{l}\text { Monosaccharide transporter } \\
\left(9,9.10^{-34}\right)\end{array}$ & ++ & + & - & - & - \\
\hline MsNod6 & - & ++ & + & - & - & - \\
\hline$M s z p t 2-1^{\mathrm{c}}$ & Zinc-finger protein & ++ & + & - & - & + \\
\hline MsNod67 & - & + & - & + & - & + \\
\hline MsNod $202^{\mathrm{c}}$ & $\begin{array}{l}\text { Cucumber basic protein } \\
\left(5,6 \cdot 10^{-39}\right) \\
\text { G. max } \mathrm{GmNod} 315\left(1,3 \cdot 10^{-4}\right) \\
\text { M. truncatula Enod20 }(1, \\
\left.0.10^{-3}\right)\end{array}$ & ++ & + & + & - & - \\
\hline $\operatorname{MsNod} 377^{\mathrm{d}}$ & L3 Ribosomal protein & ++ & + & + & - & + \\
\hline MsNod447 & - & ++ & + & + & - & + \\
\hline MsNod $448^{\mathrm{d}}$ & VfEnod-GRP5 & ++ & + & + & - & + \\
\hline Enod40 & - & ++ & + & + & - & + \\
\hline MsNod398 & - & ++ & + & + & + & + \\
\hline MsNod605 & $\begin{array}{l}\text { GASA5-like protein } \\
\left(6,5 \cdot 10^{-30}\right)\end{array}$ & ++ & + & + & + & + \\
\hline MsNod658 & $\begin{array}{l}\text { DnaJ protein homolog } \\
\left(2,5.10^{-130}\right)\end{array}$ & ++ & + & + & + & + \\
\hline \multicolumn{7}{|c|}{ Nodule-repressed transcript } \\
\hline$M s c 191^{\mathrm{d}}$ & $\begin{array}{l}O \text {-diphenol- } O \text {-methyl trans- } \\
\text { ferase }\left(2,2 \cdot 10^{-58}\right)\end{array}$ & - & + & + & - & - \\
\hline
\end{tabular}

${ }^{a}$ Indicates results from a search in the nonredundant protein data base with the BLASTX algorithm (Gish and States 1993). -, No significant homology.

${ }^{\mathrm{b}} \mathrm{N}$, nodules; R, roots; S, stems; L, leaves; F, flowers. Qualitative observations: - , transcript not detected; +, presence of the transcript; ++, enhanced expression in nodule tissues.

${ }^{c}$ Full-length cDNAs.

${ }^{\mathrm{d}}$ Identical clones were previously identified with a cold-plaque screening approach from spontaneous nodules (Mscp17, Mscp7 and Mscp5; Frugier et al. 1998). tissues, mainly in stems and flowers. In leaves, only three of the tested clones (MsNod398, MsNod605, MsNod658) were expressed.

\section{Expression of MsNod genes depends on different rhizobial signal molecules.}

Nodule development can be arrested at different stages by means of rhizobial mutants impaired in the production of putative signaling molecules required to establish an effective symbiotic association. In the next series of experiments (Fig. 2 ), cDNA arrays were analyzed for expression in uninoculated alfalfa roots, in spontaneous, nodulelike structures obtained in the absence of $S$. meliloti ( $\mathrm{Nar}^{+}$plants), in roots inoculated with the Nod mutant ZB138 (Kondorosi et al. 1984), in nodules induced by the Eps ${ }^{-}$AK1492 mutant strain (Kondorosi et al. 1984; Putnoky et al. 1988) or $\mathrm{Bac}^{-} \mathrm{Sm} 8368$ mutant strain (Glazebrook et al. 1993) (in Figure 2, $\mathrm{Exo}^{-}$and $\mathrm{Bac}^{-}$nodules, respectively), and in young and mature $\mathrm{Sm} 41$-induced nodules (nodules 5 and 14 days old, respectively). All bacterial inoculations were performed on plant roots grown in the absence of combined nitrogen. The hybridization patterns for each tissue are shown in Figure 2A and the deduced correlation between MsNod gene expression and the different stages of nodule development controlled by bacterial signals is presented in Figure $2 \mathrm{~B}$.

With the exception of the Mszpt2-1 gene, similar expression profiles were observed in control roots and nitrogen-starved roots inoculated with the $\mathrm{Nod}^{-}$mutant strain ZB138, which is unable to elicit any developmental response in the host plant due to the lack of Nod factor production (data not shown). The levels of the transcript corresponding to the Mszpt2-1 gene increased in $\mathrm{Nod}^{-}$mutant-inoculated roots, in spontaneous and Exo $^{-}$nodules, and to a lower extent in symbiotic nodules (Fig. 2A) when compared with control roots, where its expression was not detectable (data not shown).

Overall, most of the clones were confirmed to be differentially expressed in nitrogen-starved roots and developing or mature, symbiotic, nitrogen-fixing nodules. However, comparison of expression profiles in root tissues and spontaneous nodules revealed that 10 genes included in this analysis were up-regulated in these structures. Within this group are included the homologs of the L3 ribosomal protein (MsNod377), the putative HMG1 protein (MsNod398), the gibberellinregulated protein (MsNod605), the DnaJ protein (MsNod658), the wound-induced protein (MsNod660), the monosaccharide transporter (MsNod800), the aforementioned zinc-finger protein (Mszpt2-1), the Enod40 gene, and the two coding sequences MsNod447 and MsNod898. Although these genes also showed enhanced expression in the $S$. meliloti-induced nodules, transcript levels of MsNod377, MsNod398, MsNod447, and MsNod658 decreased in mature, nitrogenfixing, nodule tissues, suggesting that their putative protein products are likely to function during nodule formation.

The mutant strain AK1492, devoid of EPSs and KPSs (Eps ${ }^{-}$ $\mathrm{Kps}^{-}$), is unable to invade the nodules. Nevertheless, it generates bacteria-free outgrowths, probably due to Nod factor action whose production is unaffected by the mutation. When comparing the expression profiles in roots, spontaneous nodules, and $\mathrm{Exo}^{-}$nodules, induced or enhanced expression was observed for the homologs of already reported nodulin genes GmNod26 (MsNod20), MtN20, MtN26 (MsNod202), 
GmEnod93 (MsNod647), and VfEnod-GRP5 (MsNod448) as well as for four novel cDNAs with no similarity to sequences in data banks, MsNod6, MsNod236, MsNod512, and MsNod559. Thus, these molecular markers constitute a group of putative genes likely controlled by the Nod factor signal transduction pathway.

The $S$. meliloti 8368 mutant (BacA386) is able to infect the host but does not differentiate into bacteroids $\left(\mathrm{Bac}^{-}\right)$, thereby forming nonfunctional nodules where bacteria remain in the infection threads. Transcripts corresponding to clones MsNod67, MsNod135, MsNod374a, MsNod607, MsNod940, and MsNod648, which are not or barely detectable in Exo ${ }^{-}$ nodules, are readily detected in $\mathrm{Bac}^{-}$nodules, suggesting that their expression requires at least a polysaccharide signal of bacterial origin and/or the invasion of root cortical cells. In addition, comparison of hybridization signal intensities displayed by MsNod cDNAs in BacA386- and Sm41-induced nodules revealed a lower expression level of clone $M s N o d 374 b$ in nodules induced by the mutant strain, thus rendering this gene a putative molecular marker for the bacteroid differentiation process.

Finally, the gene coding for a caffeic-acid- $O$-methyl transferase (Msc191) showed constitutive expression in roots, in $\mathrm{Exo}^{-}$, and $\mathrm{Nar}^{+}$nodules, whereas it was down-regulated in nitrogen-fixing and $\mathrm{Bac}^{-}$nodules, where infection of bacteria occurs.

\section{Certain MsNod transcripts accumulate in 2,4-D- and BAP- treated alfalfa roots.}

It has been suggested that phytohormonal imbalances created in the root cortex by the Nod factors can act as secondary signals during nodule organogenesis (Hirsch 1992; Hirsch and Fang 1994). We have compared the expression profiles of the MsNod ESTs in untreated M. sativa roots and in roots treated with a synthetic auxin $(2,4-\mathrm{D} ; 2,4-\mathrm{D}[2,4-$ dichlorophenoxyacetic acid]) or cytokinin (BAP; 6benzylaminopruine) for 2 and 4 days. Individual hybridization signal intensities were measured and normalized to that displayed by the constitutive control gene Msc27. Data obtained in this analysis are shown in Figure 3. Only seven out of the 28 genes included in this study were found to be upregulated in BAP-treated roots showing four- to 16 -fold induction of their expression levels. These are the genes coding for homologs of an L3 ribosomal protein (MsNod377), a gibberellin-regulated protein (MsNod605), a wound-induced protein (MsNod660), a zinc-finger protein (Mszpt2-1), the VfEnod-GRP5 (MsNod448) and Enod40 genes, and the MsNod447 cDNA. The Enod40 gene was previously shown to be induced by cytokinins (Fang and Hirsch 1998), whereas induction by these plant hormones has not been reported for the other genes in this group.
None of the genes was induced by the 2,4-D treatment alone. However, four out of the seven cytokinin-induced genes (MsNod448, MsNod447, MsNod605, and Mszpt2-1) also responded positively to 2,4-D treatment, albeit to much lesser extent than to BAP application. Induction levels between fourand sevenfold were detectable only 4 days after root treatment. The MsNod605 transcript exhibited the highest accumulation level among those analyzed in alfalfa roots treated with either 2,4-D or BAP. No alteration in the expression profiles of the other genes included in this study was detected after phytohormone treatments.

\section{Elevated levels of the $M$. sativa $\mathrm{L} 3$ ribosomal protein gene MsNod377 in transgenic Enod40-overexpressing plants.}

Enod40 is a key regulatory gene expressed early during nodule organogenesis. In order to search for genes acting downstream in an Enod40-dependent pathway, the expression profiles of the MsNod transcripts were analyzed in roots of the M. truncatula 108R ecotype and of transgenic derivatives overexpressing the Enod40 gene (Se40). The intensities of the hybridization signals were quantified and normalized as described above. As expected, the Enod40 transcript was found to be about 20 -fold more abundant in Se 40 plant roots. Interestingly, fourfold induction of the L3 ribosomal protein transcript (MsNod377) was also observed in the Se40 plant roots in two independent cDNA array experiments, whereas the expression levels of the rest of the genes were unaffected in this transgenic line (data not shown). These results were then confirmed by RT-PCR analysis (Fig. 4). RNA from leaves and roots of control and Se40 plants was reverse transcribed and the resulting cDNAs were amplified with primers specific for the constitutive control Msc27, the Enod40, and the MsNod377 genes. As expected, basal expression of Enod40 could be detected in roots and leaves of control plants while in the same tissues of the transgenic plants the expression was found to be induced 12- and 32-fold, respectively. MsNod377 transcripts were not detected in control plant tissues. However, in roots and leaves of Se40 plants, this gene was present at 25- and sixfold induced levels, respectively.

\section{DISCUSSION}

In this paper we report the expression analysis of $28 \mathrm{M}$. sativa transcripts (MsNod), 22 of them novel, nodule-associated ESTs. This study enabled us to assign molecular markers for different organogenetic pathways acting during nodule development. In addition, we have identified a gene, MsNod377, encoding an L3 ribosomal protein, with enhanced expression in transgenic Enod40-overexpressing plants.

Molecular genetic characterization of the nodulation process has been hampered by the lack of efficient targeting sys-

Fig. 2. MsNod gene expression during nodule organogenesis and rhizobial invasion. A, MsNod clone hybridization profiles in roots and different nodule types. Filters containing cDNAs arrays corresponding to clones indicated at top of panel were hybridized with radiolabeled cDNA probes obtained from: nitrogen-starved roots inoculated with a Nod ${ }^{-}$Sinorhizobium meliloti mutant strain (Nod ${ }^{-}$roots), symbiotic nodules collected 5 and 14 days after inoculation with wild-type $\mathrm{Sm} 41$ (nodules 5 days and 14 days, respectively), nodules induced by Bac ${ }^{-}$Bac $^{-}$nodules) or Eps $^{-} \mathrm{Kps}^{-}$(Exo ${ }^{-}$nodules) $S$. meliloti mutant strains, and spontaneous nodules (Nar ${ }^{+}$nodules). B, Grouping of MsNod genes according to putative bacterial signaling requirements for their expression. Arrows indicate expression profiles in different nodule types. Transcript levels corresponding to genes identified by asterisks diminished in mature symbiotic nodules, compared with expression levels observed in young or $S$. meliloti mutant-induced nodules. Differences in gene expression levels were scored visually. 
A MsNod clone

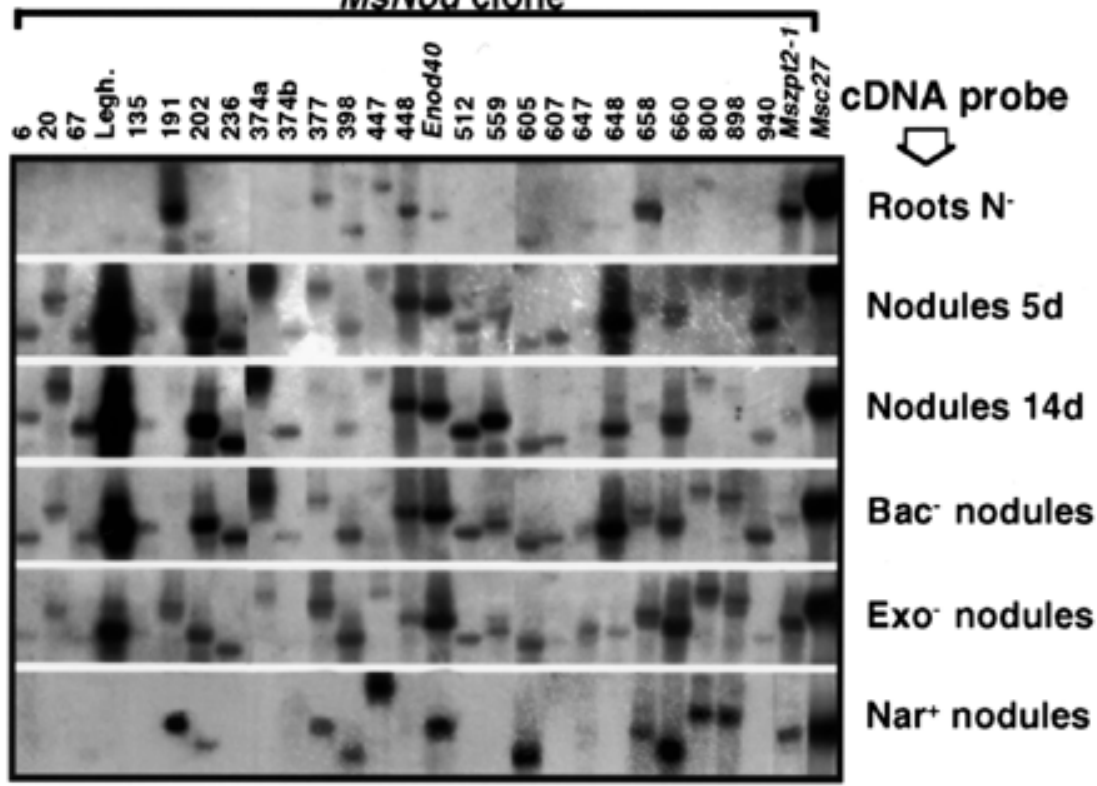

B

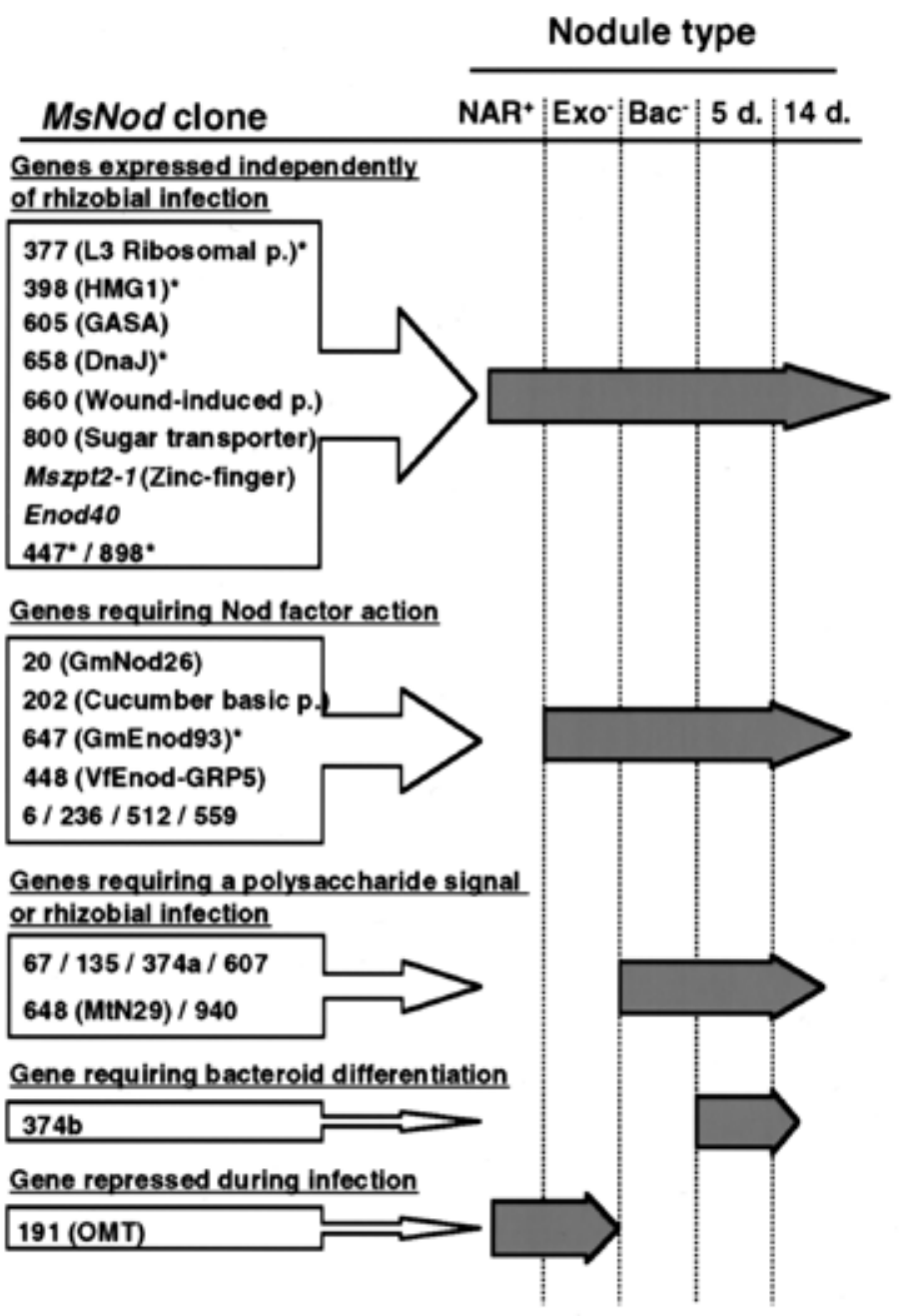


tems as well as the complexity of positional cloning in legumes. An alternative strategy consists of the isolation of plant genes induced at different stages of nodule development combined with reverse genetic approaches. In addition, the characterized nodulins proved to be useful as molecular makers of cell- or tissue-specific responses to environmental factors, as well as to bacterial and endogenous plant signal molecules likely controlling the nodulation process (Bladergroen and Spaink 1998). In the present work, a cold-plaque screening procedure (Frugier et al. 1998) allowed us to identify genes expressed before the onset of nitrogen fixation during symbiotic nodule development. Screening of 1,000 cold-plaques resulted in the isolation of 22 novel, nodule-associated $M$. sativa transcripts, in addition to 16 clones corresponding to known nodulin genes. PCR blots of cDNA arrays were then used to study global gene expression profiles under a variety of conditions, as recently reported in several plant, yeast, and mammalian systems (Schena et al. 1996; Wodika et al. 1997; Desprez et al. 1998; Ruan et al. 1998).

Almost half of the identified genes showed nodule-specific expression whereas variable expression patterns in different organs were found for the rest. This latter pattern has also been shown for several nodulin genes, particularly for early nodulin genes, suggesting that genes for vegetative development may have been recruited to function during nodulation (Bladergroen and Spaink 1998). To gain insight into the symbiotic functions of the isolated MsNod genes we analyzed their expression profiles in several nodule types induced by rhizobial mutants blocking nodulation at different developmental stages. In this way it is possible to explore signal

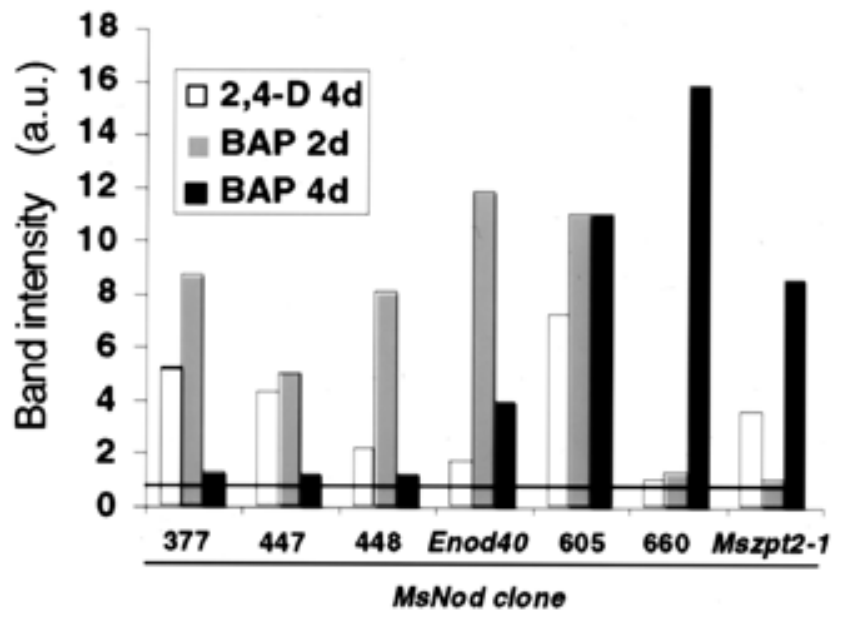

Fig. 3. Induction of MsNod gene expression by phytohormones. The set of membranes containing polymerase chain reaction (PCR) products of the MsNod clones were hybridized with radiolabeled cDNA probes from untreated and $10 \mu \mathrm{M}$ cytokinin (BAP)- or auxin (2,4-D)-treated alfalfa roots. Treatments were performed for 2 and 4 days. Hybridization signal intensities in each condition were measured and normalized to those displayed by the constitutive control Msc27 (horizontal line in the graph) with the Phosphor-imager STORM and its specific software package (Molecular Dynamics, Sunnyvale, CA). Histogram shows transcript levels (in arbitrary units, a. u.) determined after each treatment. Expression levels of MsNod transcripts were unaffected after 2 days application of 2,4-D; data are not plotted. Because internal repetitions of constitutive control gene yielded up to a twofold difference in hybridization signal intensities, threefold difference was established as the criterion for induction in this analysis. transduction pathways and establish a functional relation between signals and plant gene expression during nodule development. The fact that nitrogen starvation induces the formation of nodulelike structures (spontaneous nodules) in certain alfalfa ecotypes suggested that the expressed genes in these particular organs are involved in the nodule organogenesis program independently of any infection process (Truchet et al. 1989; Crespi et al. 1994; Coba de la Peña et al. 1997; Frugier et al. 1998). Interestingly, with two exceptions (clones MsNod447 and MsNod898), all the genes classified in our analysis as up-regulated in spontaneous nodules showed significant homologies to previously identified genes. Notably, MsNod800 codes for a monosaccharide transporter that contributes to support the increased sugar demands of mycorrhizal root cortical cells (Harrison 1996). This metabolic requirement might be a common phenomenon occurring in both

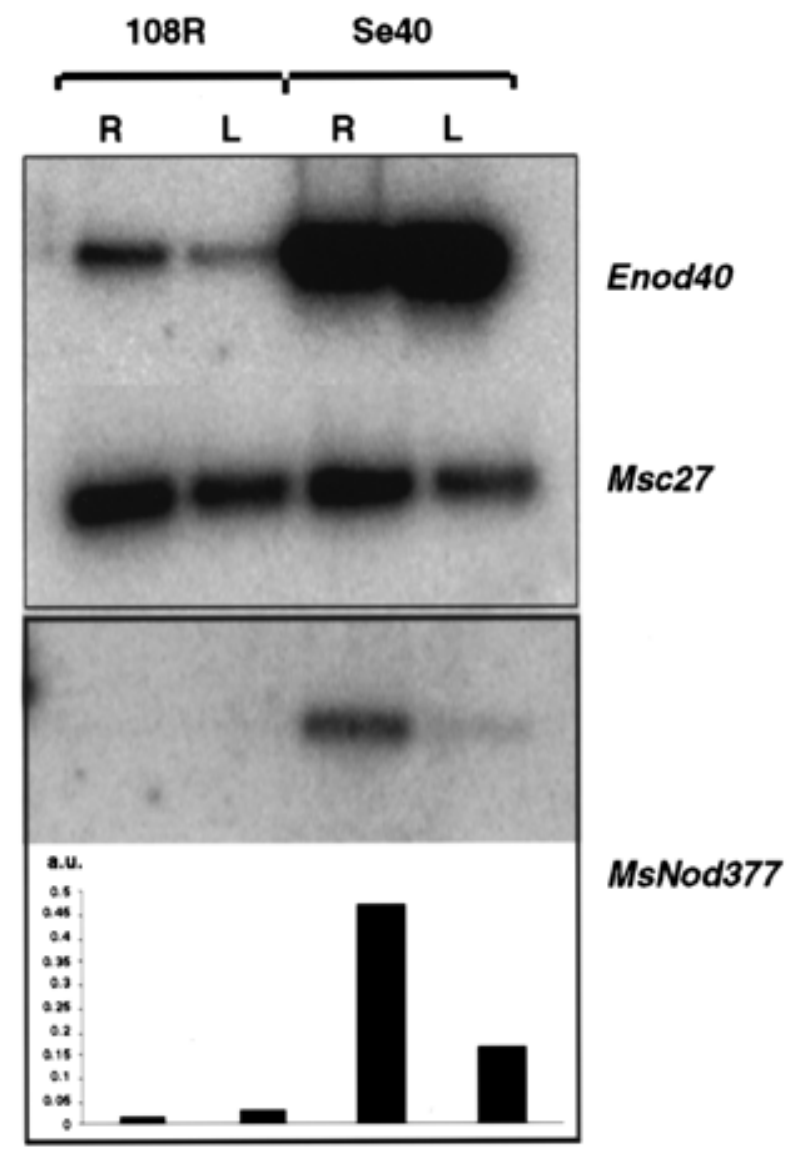

Fig. 4. Identification of a putative component of an Enod40-dependent signaling pathway. Reverse transcription-polymerase chain reaction (RT-PCR) expression analysis on RNAs from roots and leaves of the Medicago truncatula wild-type ecotype 108R and the transgenic line Se40(1) $\left(\mathrm{T}_{1}\right.$ generation) overexpressing the early nodulin Enod40 gene. Synthesized cDNAs were PCR amplified with primers specific for the Enod40, MsNod377, and Msc27 sequences (15 cycles for Msc27 and 20 for Enod40 and MsNod377). PCR products were detected by hybridization with the corresponding probes. Clone MsNod377 was previously selected for this analysis on the basis of the expression profile comparison of the MsNod genes in the wild-type and transgenic roots. Shown is a picture obtained with the Phosphor-imager STORM and a graph plotting MsNod377 transcript levels in wild-type and transgenic plant tissues normalized to the $M s c 27$ value (arbitrary units, a. u.). In all experiments, water was included as negative control for the PCR. R, roots; L, leaves. 
mycorrhizal and rhizobial symbioses as well as in organogenesis of spontaneous nodules.

The remaining genes require the presence of rhizobia for their expression. Nodules induced by $\mathrm{Exo}^{-}$strains form few infection threads that abort in the outer cortex or the epidermis, and a persistent meristem could not be detected (Yang et al. 1992; Becker and Pühler 1998). Hence, genes expressed in these nodules but not in spontaneous nodules are putative targets of a restricted Nod factor signaling pathway involved in the initial infection process. Three alfalfa homologs of early nodulin genes in addition to one putative late nodulin were found in this group, further supporting this hypothesis. Notably, MsNod647 and MsNod20 code for alfalfa homologs of the soybean early nodulin GmEnod93 (Kouchi and Hata 1993) and nodulin GmNod26 (Miao and Verma 1993), respectively. This supports the view that both proteins have common functions in the development of determinate and indeterminate nodule types. Genes not expressed in Exo ${ }^{-}$nodules but detected in wild-type nodules are probably linked to the invasion process in root tissues. Five of the MsNod clones exhibiting this feature are novel plant genes and one, MsNod648, shows weak homology to the $M$. truncatula nodulin MtN29. These constitute novel molecular markers to explore Eps/Kpsdependent plant responses during nodulation. Furthermore, the clone Msc191, corresponding to a gene repressed during rhizobial invasion, exhibits strong homology to a gene encoding $O$-diphenol- $O$-methyl transferase in Capsicum annuum. $O$ methyl transferases (OMTs) are enzymes that methylate specific substrates and are encoded by genes induced at the onset of lignification in plants responding to infection by viruses (Jaeck et al. 1992) and fungi (Maule and Ride 1976). Alfalfa homologs of genes coding for caffeic acid-OMT, caffeoil coenzyme A-OMT (Inoue et al. 1998), and isoliquiritigenin 2',4,4'-trihydroxychalcone-OMT (chalcone-OMT) (Maxwell et al. 1993) have been already cloned and characterized. Similar to Msc191, these genes are primarily expressed in alfalfa roots and are repressed in symbiotic nodules. Msc191 transcripts are also very abundant in $\mathrm{Exo}^{-}$nodules that accumulate precursors for plant cell wall lignification (Niehaus et al. 1993). This supports the hypothesis that this gene might be a first molecular marker of mechanisms underlying EPSmediated avoidance of plant defense responses (Niehaus et al. 1998). Finally, only one gene (MsNod374b) seems to require bacteroid differentiation for its expression at the same level as in mature nodules, suggesting that it may be implicated in a pathway involved in the symbiosome-plant communication.

Several reports have described the capacity of cytokinins and auxin transport inhibitors to up-regulate several early nodulin genes and to mimic certain Nod factor-dependent responses on leguminous roots (e.g., cortical cell division, amyloplast deposition; Hirsch et al. 1989; Cooper and Long 1994; Bauer et al. 1996; Silver et al. 1996; Fang and Hirsch 1998). Indeed, our expression analysis indicates that all cytokinin-induced MsNod genes belong to the group of genes expressed in spontaneous nodules, or depend on Nod factor action. Treatment with the synthetic auxin 2,4-D showed slight effects on MsNod gene expression, further supporting the hypothesis that cytokinins rather than auxins might be secondary signals elicited by Nod factors (Hirsch and Fang 1994; Bauer et al. 1996; Silver et al. 1996; Fang and Hirsch 1998).
Few early nodulin genes have been functionally analyzed with reverse genetics. Recently, it has been shown that Enod40 overexpression leads to the division of cortical cells in Medicago spp. (Charon et al. 1997), and we explored whether certain of the identified molecular markers would be targets of this gene. An alfalfa L3 ribosomal protein homolog, showing the same organ-specific expression profile and cytokinin inducibility as Enod40, was found to be concomitantly expressed at high levels in Enod40-overexpressing plants. Because Enod40 is a Nod factor-inducible gene (Crespi et al. 1994; Minami et al. 1996; Fang and Hirsch 1998) we propose that MsNod377 may be a downstream component of an Enod40-dependent Nod factor signaling pathway acting in nodule development. Interestingly, growth-related gene expression has also been found for an L2 ribosomal protein in tobacco protoplasts (Marty et al. 1993). Thus, MsNod377 can be used as a marker to explore molecular mechanisms of Enod40 action in cortical cell division events preceding rhizobial infection in early nodule developmental stages.

In summary, we have provided a framework for the investigation of a broad group of nodulation-enhanced genes that could be used to study gene networks and regulatory circuits controlling nodule organogenesis. These studies coupled to the analysis of mutant and transgenic plants affected in symbiotic nodule development will define functional relationships in the signaling pathways involved in this developmental process.

\section{MATERIALS AND METHODS}

\section{Bacterial strains.}

Bacterial strains used for plant inoculations and nodule production were as follows: (i) the wild-type $S$. meliloti strain 41; (ii) the non-nodulating mutant derivative of Sm41, ZB138 ( $\mathrm{Nod}^{-}$strain) resulting from deletion of all nod genes identified in the pSym megaplasmid (Kondorosi et al. 1984); (iii) the $\mathrm{Bac}^{-}$mutant strain Sm8368, an Sm1021 derivative obtained by TnphoA insertion in the bacA gene (Glazebrook et al. 1993); and (iv) the AK1492 (Eps ${ }^{-} \mathrm{Kps}^{-} \mathrm{Fix}^{-}$) mutant, a spontaneous $\mathrm{Exo}^{-}($exoB $)$derivative of $\mathrm{Sm} 41$ containing a $\mathrm{Tn} 5$ insertion in the fix-23 region, giving $\mathrm{Kps}^{-}$and $\mathrm{Fix}^{-}$phenotypes (Kondorosi et al. 1984; Putnoky et al. 1988). Bacteria were routinely grown by shaking at $30^{\circ} \mathrm{C}$ in a rich TA medium (Orosz et al. 1973) supplemented with $100 \mu \mathrm{g} \cdot \mathrm{ml}^{-1}$ kanamycin for the mutant strains.

\section{Plant material and phytohormones treatments.}

Alfalfa (Medicago sativa subsp. sativa cv. Sitel) seeds were sterilized in 20\% Inov'Chlore (Inov'Chem, Tanneries, France) for $1 \mathrm{~h}$ at $28^{\circ} \mathrm{C}$ by shaking, rinsed 4 times with water, incubated overnight at $28^{\circ} \mathrm{C}$ in a $200 \mathrm{mg} \cdot \operatorname{liter}^{-1}$ augmentin solution, rinsed 3 times, and germinated for $24 \mathrm{~h}$ in the dark on $1 \%$ water agar plates. Seedlings were then transferred to fresh water agar plates and incubated for 3 to 4 days in a growth chamber at $24^{\circ} \mathrm{C}$ under a 16 -h light period. Plantlets were then grown aeroponically in nitrogen-limiting medium (Crespi et al. 1994) for 1 week, and then inoculated with $100 \mathrm{ml}$ of a $\log$ culture of the different $S$. meliloti strains. Wild-type Sm41induced nodules were harvested 5 and 14 days after inoculation whereas nodules induced by the $\mathrm{Bac}^{-}$and $\mathrm{Exo}^{-}$mutants were excised from roots 2 to 3 weeks after infection. Nitro- 
gen-grown roots, leaves, flowers, and stems of plants were also collected and used in experiments to assess organspecific expression of selected clones.

$M$. sativa subsp. varia genotype $\mathrm{A}_{2} \mathrm{NAR}^{+}$plants were used for the induction of spontaneous nodules (Crespi et al. 1994) and for BAP (cytokinin) and 2,4-D (auxin) treatments as previously described (Bauer et al. 1996).

The wild-type 108R ecotype of the model legume $M$. truncatula and the transgenic line $\operatorname{Se} 40(1)\left(\mathrm{T}_{1}\right.$ generation) overexpressing the early nodulin gene MtEnod40 (Charon et al. 1997) were also grown in aeroponic conditions as described above.

\section{Cold-plaque screening and serial analysis of gene expression.}

Initially, a cDNA library of young $M$. sativa A2 nodules constructed in $\lambda$ ZAP phages (McKhann et al. 1997) was differentially screened as described in Crespi et al. (1994) with Sm41-induced nodules (collected 5 days post inoculation) versus ZB138 ( Nod $^{-}$mutant) inoculated roots cDNA probes. A thousand clones giving no or faint hybridization signal to either of the probes were randomly selected (cold-plaques) and pooled in 250 groups (four phages each). To identify and isolate individual differentially expressed transcripts, two rounds of PCR blotting (PCR amplification of phage inserts, agarose electrophoresis, and transfer to nylon membranes; Frugier et al. 1998) and hybridization with freshly prepared cDNA probes were then performed. The first round was carried out on groups of phages and the second on the individual clones of those groups giving any differential signal after the first PCR blotting. Selected individual phages containing appropriate clones were transferred to their corresponding plasmid forms by in vivo excision for sequencing and storage.

For serial analysis of gene expression, several sets of membranes were prepared, each containing the PCR amplification products of the cDNA inserts previously resolved in $1 \%$ agarose gels, and subsequently hybridized with complex cDNA probes derived from different alfalfa tissues. The cDNA probes were generated with Superscript reverse transcriptase (Life Technologies, Paisley, UK) with total RNAs extracted as previously described (Charon et al. 1997). Hybridizations were performed at $65^{\circ} \mathrm{C}$ and membranes were subsequently washed for $30 \mathrm{~min}$ each with $2 \times \mathrm{SSC}(1 \times \mathrm{SSC}$ is $0.15 \mathrm{M} \mathrm{NaCl}$ plus $0.015 \mathrm{M}$ sodium citrate) / $0.1 \%$ SDS and $1 \times \mathrm{SSC} / 0.1 \%$ SDS and exposed to Kodak films. Transcript levels in Figures 3 and 4 were quantified by measuring the intensities of the hybridization signals with the Phosphor-imager STORM and specific computer software packages (Molecular Dynamics, Uppsala, Sweden).

\section{Northern and RT-PCR analysis.}

Northern analysis was performed with $10 \mu \mathrm{g}$ of total RNA from roots and nodules extracted by standard protocols (Sambrook et al. 1989).

RT and PCR were performed as described (Crespi et al. 1994). Total RNA (2 to $10 \mu \mathrm{g}$ ) pretreated with DNase (FPLC pure; Amersham Pharmacia Biotech, Uppsala, Sweden) was reverse transcribed with Superscript reverse transcriptase (Life Technologies, Paisley, UK) with oligo-dT to prime the reaction. The synthesized cDNAs were amplified for different cycles of PCR depending on the gene being studied (15 for
Msc27 and 20 for Enod40 and MsNod377). Amplified cDNAs were subjected to electrophoresis and blotted to nylon membranes. Control reactions for genomic DNA contaminations were performed with the same amount of DNase-treated RNAs templates before reverse transcription.

Specific radiolabeled DNA probes to hybridize Northern and RT-PCR blots were generated by random priming from the individual cDNA inserts with the Megaprime labeling kit (Amersham Pharmacia Biotech, Uppsala, Sweden). In each case, $M s c 27$ was used as constitutive control of gene expression (Pay et al. 1992).

\section{Sequence analysis.}

The whole nucleotide sequence of the selected cDNAs was determined in an automatic laser sequencer 373A (Applied Biosystems, Foster City, CA) by the chain terminator method (Pharmacia kit, Uppsala, Sweden) with universal T3 and T7 primers of pBluescript SK and specific oligonucleotides when required. Sequence editing, translation, and analysis were done with the GCG software package (Program Manual for the Wisconsin Package, version 8; University of Wisconsin, Madison, WI). BLAST (Gish and States 1993) and FASTA (Pearson and Lipman 1989) programs were used for homology searches.

\section{ACKNOWLEDGMENTS}

We thank C. Charon for advice on Se40 plants, L. Troussard for sequencing, N. Mansion for photographic help, and B. G. Rolfe for critical reading of the manuscript. J. I. J. Z. was supported by an EC Marie Curie research training grant (contract EC BIO4CT975006) and F. F. by a fellowship of the Ministère Français de l'Education Supérieure et de la Recherche.

\section{LITERATURE CITED}

Asad, S., Fang, Y., Wycoff, K. L., and Hirsch, A. M. 1994. Isolation and characterization of cDNA and genomic clones of MsENOD40; transcripts are detected in meristematic cells. Protoplasma 183:10-23.

Aubert, D., Chevillard, M., Dorne, A.-M., Arlaud, G., and Herzog, M. 1998. Expression patterns of GASA genes in Arabidopsis thaliana: The GASA4 gene is up-regulated by gibberellins in meristematic regions. Plant. Mol. Biol. 36:871-883.

Bauer, P., Ratet, P., Crespi, M. D., Schultze, M., and Kondorosi, A. 1996. Nod factors and cytokinins induce similar cortical cell division, amyloplast deposition and MsEnod $12 A$ expression patterns in alfalfa roots. Plant J. 10:91-105.

Becker, A., and Pühler, A. 1998. Production of exopolysaccharides. Pages 97-118 in: The Rhizobiaceae. Herman P. Spaink, Adam Kondorosi, and Paul J. J. Hooykaas, eds. Kluwer, Dordrecht, The Netherlands.

Bladergroen, M. R., and Spaink, H. P. 1998. Genes and signal molecules involved in the rhizobia-Leguminoseae symbiosis. Curr. Opin. Plant Biol. 1:353-359.

Caetano-Anollés, G., and Gresshoff, P. M. 1991. Plant genetic control of nodulation. Annu. Rev. Microbiol. 45:345-382.

Charon, C., Johansson, C., Kondorosi, E., Kondorosi, A., and Crespi, M. D. 1997. Enod40 induces dedifferentiation and division of root cortical cells in legumes. Proc. Natl. Acad. Sci. USA 94:8901-8906.

Coba de la Peña, T., Frugier, F., McKhann, H. I., Bauer, P., Brown, S., Kondorosi, A., and Crespi, M. 1997. A carbonic anhydrase gene is induced in the nodule primordium and its cell-specific expression is controlled by the presence of Rhizobium during development. Plant J. 11:407-420.

Cook, D., Dreyer, D., Bonnet, D., Howell, M., Nony, E., and VandenBosh, K. 1995. Transient induction of a peroxidase gene in Medicago truncatula precedes infection by Rhizobium meliloti. Plant Cell 7:4355 . 
Cooper, J. B., and Long, S. R. 1994. Morphogenetic rescue of Rhizobium meliloti nodulation mutants by trans-zeatin secretion. Plant Cell 6:215-225.

Crespi, M. D., Jurkevitch, E., Poiret, M., D'Aubenton-Carafa, Y., Petrovics, G., Kondorosi, E., and Kondorosi, A. 1994. Enod40, a gene expressed during nodule organogenesis, codes for a non-translatable RNA involved in plant growth. EMBO J. 13:5099-5112.

de Blank, C., Mylona, P., Yang, W. C., Katinakis, P., Bisseling, T., and Franssen, H. 1993. Characterization of the soybean early nodulin cDNA clone GmENOD55. Plant. Mol. Biol. 22:1167-1171.

Dénarié, J., Debellé, F., and Promé, J.-C. 1996. Rhizobium lipo-chitooligosaccharide nodulation factors: Signaling molecules mediating recognition and morphogenesis. Annu. Rev. Biochem. 65:503-535.

Desprez, T, Amselem, J., Caboche, M., and Höfte, H. 1998. Differential gene expression in Arabidopsis monitored using cDNA arrays. Plant J. 14:643-652.

Fang, Y., and Hirsch, A. M. 1998. Studying early nodulin gene ENOD40 expression and induction by nodulation factor and cytokinin in transgenic alfalfa. Plant Physiol. 116:53-68.

Franssen, H. J., Nap, J.-P., and Bisseling, T. 1992. Nodulins in root nodule development. Pages 598-624 in: Biological Nitrogen Fixation, G. Stacey, R. H. Burris, and H. J. Evans, eds. Chapman and Hall, New York.

Franssen, H. J., Nap, J.-P., Gloudemans, T., Stiekema, W., van Dam, H., Govers, F., Louwerse, J., van Kammen, A., and Bisseling, T. 1987. Characterization of cDNA for nodulin-75 of soybean: A gene product involved in early stages of root nodule development. Proc. Natl. Acad. Sci. USA 84:4495-4499.

Frugier, F., Kondorosi, A., and Crespi, M. 1998. Identification of novel putative regulatory genes induced during alfalfa nodule development with a cold-plaque screening procedure. Mol. Plant-Microbe Interact. 11:358-366.

Gamas, P., de Carvalho Niebel, F., Lescure, N., and Cullimore, J. V. 1996. Use of a subtractive hybridization approach to identify new Medicago truncatula genes induced during root nodule development. Mol. Plant-Microbe Interact. 9:233-242.

Gish, W., and States, D. J. 1993. Identification of protein coding regions by database similarity search. Nature Genet. 3:266-272.

Glazebrook, J., Ichige, A., and Walker, G. C. 1993. A Rhizobium meliloti homolog of the Escherichia coli peptide-antibiotic transport protein SbmA is essential for bacteroid development. Genes Dev. 7:14851497

Goormachtig, S., Valerio-Lepiniec, M., Szczyglowski, K., Van Montagu, M., Holsters, M., and de Bruijn, F. J. 1995. Use of differential display to identify novel Sesbania rostrata genes enhanced by Azorhizobium caulinodans infection. Mol. Plant-Microbe Interact. 8:816-824.

Greene, E. A., Erard, M., Dedieu, A., and Barker, D. G. 1998. MtENOD16 and 20 are members of a family of phytocyanin-related early nodulins. Plant Mol. Biol. 36:775-783.

Harrison, M. J. 1996. A sugar transporter from Medicago truncatula: Altered expression pattern in roots during vesicular-arbuscular (VA) mycorrhizal associations. Plant J. 9: 491-503.

Herzog, M., Dorne, A.-M., and Grellet, F. 1995. GASA, a gibberellinregulated gene family from Arabidopsis thaliana related to the tomato GAST1 gene. Plant Mol. Biol. 27:743-752.

Hirsch, A. M. 1992. Developmental biology of legume nodulation. New Phytol. 122:211-237.

Hirsch, A. M., Bhuvaneswari, T. V., Torrey, J. G., and Bisseling, T. 1989. Early nodulin genes are induced in alfalfa roots outgrowths elicited by auxin transport inhibitors. Proc. Natl. Acad. Sci. USA 86: 1244-1248.

Hirsch, A. M., and Fang, Y. 1994. Plant hormones and nodulation: What's the connection? Plant Mol. Biol. 26:5-9.

Inoue, K., Sewalt, V. J. H., Murray Ballance, G., Ni, W., Stürzer, C., and Dixon, R. A. 1998. Developmental expression and substrate specificities of alfalfa caffeic acid 3-O-methyltransferase and caffeoil coenzyme A 3-O-methyltransferase in relation to lignification. Plant Physiol. 117:761-770.

Jaeck, E., Dumas, B., Geoffroy, P., Favet, N., Inzé, D., Van Montagu, M., Fritig, B., and Legrand, M. 1992. Regulation of enzymes involved in lignin biosynthesis: Induction of $O$-methyltransferase mRNAs during the hypersensitive reaction of tobacco to tobacco mosaic virus. Mol. Plant-Microbe Interact. 5:294-300.

Kannenberg, E. L., Reuhs, B. L., Forsberg, L. S., and Carlson, R. W.
1998. Lipopolysaccharides and K-antigens: Their structures, biosynthesis, and functions. Pages 119-154 in: The Rhizobiaceae. Herman P. Spaink, Adam Kondorosi, and Paul J. J. Hooykaas, eds. Kluwer, Dordrecht, The Netherlands.

Kondorosi, E., Banfalvi, Z., and Kondorosi, A. 1984. Physical and genetic analysis of a symbiotic region of Rhizobium meliloti: Identification of nodulation genes. Mol. Gen. Genet. 193:445-452.

Kouchi, H., and Hata, S., 1993. Isolation and characterization of novel nodulins cDNAs representing genes expressed at early stages of soybean nodule development. Mol. Gen. Genet. 238:106-119.

Lee, B., Choi, D., and Lee, K.-W. 1998. Isolation and characterization of $O$-diphenol- $O$-methyltransferase cDNA clone in hot pepper (Capsicum annuum L.). J. Plant Biol. 41:9-14.

Legocki, R. P., and Verma, D. P. S. 1980. Identification of nodulespecific host proteins (nodulins) involved in the development of Rhizobium-legume symbiosis. Cell. 20:153-163.

Libbenga, K. R., Van Iren, F., Bogers, R. J., Schraag-Lamers, M. F 1973. The role of hormones and gradients in the initiation of cortex proliferation and nodule formation in Pisum sativum L. Planta 114: 29-39.

Marty, I., Brugidou, C., Chartier, Y., and Meyer, Y. 1993. Growth-related gene expression in Nicotiana tabacum mesophyll protoplasts. Plant J. 4:265-278.

Matvienko, M., Van De Sande K., Yang, W.-C., Van Kammen, A., Bisseling, T., and Franssen, H. 1994. Comparison of soybean and pea ENOD40 cDNA clones representing genes expressed during both early and late stages of nodule development. Plant Mol. Biol. 26:487493.

Maule, A. J., and Ride, J. P. 1976. Ammonia-lyase and $O$-methyl transferase activities related to lignification in wheat leaves infected with Botrytis. Phytochemistry 15:1661-1664.

Maxwell, C. A., Harrison, M. J., and Dixon, R. A. 1993. Molecular characterization and expression of alfalfa isoliquiritigenin $2^{\prime}-O$ methyltransferase, an enzyme specifically involved in the biosynthesis of an inducer of Rhizobium meliloti nodulation genes. Plant J. 4: 971-981.

McKhann, H. I., Frugier, F., Petrovics, G., De la Peña, T. C., Jurkevitch, E., Brown, S., Kondorosi, E., Kondorosi, A., and Crespi, M. 1997. Cloning of a WD-repeat-containing gene from alfalfa (Medicago sativa): A role in hormone-mediated cell division? Plant Mol. Biol. 34: 771-780.

Miao, G.-H., and Verma, D. P. S. 1993. Soybean nodulin-26 gene encoding a channel protein is expressed only in the infected cells of nodules and is regulated differently in roots of homologous and heterologous plants. Plant Cell 5:781-794.

Minami, E., Kouchi, H., Cohn, J. R., Ogawa, T., and Stacey, G. 1996 Expression of the early nodulin, ENOD40, in soybean roots in response to various lipo-chitin signal molecules. Plant J. 10:23-32.

Murata, M., Begg, G. S., Lambrou, F., Leslie, B., Simpson, R. J., Freeman, H. C., and Morgan, F. J. 1982. Amino acid sequence of a basic blue protein from cucumber seedlings. Proc. Natl. Acad. Sci. USA 79: 6434-6437.

Niehaus, K., Albus, U., Baier, R., Schiene, K., Schröder, S., and Pühler, A. 1998. Symbiotic suppression of the Medicago sativa plant defence system by Rhizobium meliloti oligosaccharides. Pages 225-226 in: Biological Nitrogen Fixation for the 21st Century. C. Elmerich, A. Kondorosi, and W. E. Newton, eds. Kluwer, Dordrecht, The Netherlands.

Niehaus, K., Kapp, D. and Pühler, A. 1993. Plant defence and delayed infection of alfalfa pseudonodules induced by an exopolysaccharide (EPS-I)-deficient Rhizobium meliloti mutant. Planta 190:415-425.

Orosz, L., Svab, Z., Kondorosi, A., and Sik, T. 1973. Genetic studies on Rhizobiophage 16-3 T; genes and function on the chromosome. Mol Gen. Genet. 125:341-350.

Pay, A., Heberle-Bors, E., and Hirt, H. 1992. An alfalfa cDNA encodes a protein with homology to translationally controlled human tumor protein. Plant Mol. Biol. 19:501-503.

Pearson, W. R., and Lipman, D. J. 1989. Improved tools for biological sequences comparison. Proc. Natl. Acad. Sci. USA 85:2444-2448.

Putnoky, P., Grosskopf, E., Cam Ha, D. T., Kiss, G. B., and Kondorosi, A. 1988. Rhizobium fix genes mediate at least two communication steps in symbiotic nodule development. J. Cell. Biol. 106:597-607.

Ruan, Y., Gilmore, J., and Conner, T. 1998. Towards Arabidopsis genome analysis: Monitoring expression profiles of 1400 genes using 
cDNA microarrays. Plant J. 15:821-833.

Sambrook, J., Fritsch, E. F., and Maniatis, T. A. 1989. Molecular Cloning: A Laboratory Manual. 2nd ed. Cold Spring Harbor Laboratory, Cold Spring Harbor, NY.

Schena, M., Shalon, D., Heller, R., Chai, A., Brown, P. O., and Davis, R. W. 1996. Parallel human genome analysis: Microarray-based expression monitoring of 1000 genes. Proc. Natl. Acad. Sci. USA 93: 10614 10619.

Scheres, B., Van de Wiel, C., Zalensky, A., Horvath, B., Spaink, H., Van Eck, H., Zwartkruis, F., Wolters, A.-M., Gloudemans, T., Van Kammen, A., and Bisseling, T. 1990a. The ENOD12 gene product is involved in the infection process during the pea-Rhizobium interaction. Cell 60:281-294.

Scheres, B., Van Engelen, F., Van der Knaap, E., Van de Wiel, C., Van Kammen, A., and Bisseling, T. 1990b. Sequential induction of nodulin gene expression in the developing pea nodule. Plant Cell 2 . 687-700.

Schröder, G., Frühling, M., Pühler, A., and Perlick, A. 1997. The temporal and spatial transcription pattern in root nodules of Vicia faba nodulin genes encoding glycine-rich proteins. Plant Mol. Biol. 33: 113-123.

Schultze, M., and Kondorosi, A. 1998. Regulation of symbiotic root nodule development. Annu. Rev. Genet. 32:33-57.

Shi, L., Gast, R. T., Goplaraj, M., and Olszewski, N. E. 1992. Characterization of a shoot specific, $\mathrm{GA}_{3}$ - and ABA-regulated gene from tomato. Plant J. 2:153-159.
Silver, D. L., Pinaev, A., Chen, R., and de Bruijn, F. J. 1996. Posttranscriptional regulation of the Sesbania rostrata early nodulin SrEnod2 by cytokinin. Plant Physiol. 112:559-567.

Smit, G., De Koster, C. C., Schripsema, J., Spaink, H. P., Van Brussel, A A., and Kijne, J. W. 1995. Uridine, a cell division factor in pea roots. Plant Mol. Biol. 29:869-873.

Szczyglowski, K., Hamburger, D., Kapranov, P., and de Bruijn, F. J. 1997. Construction of a Lotus japonicus late nodulin expressed sequence tag library and identification of novel nodule-specific genes. Plant Physiol. 114:1335-1346.

Truchet, G., Barker, D. G., Camut, S., De Billy, F., Vasse, J., and Huguet, T. 1989. Alfalfa nodulation in the absence of Rhizobium. Mol. Gen. Genet. 219:65-68.

Wodicka, L., Dong, H., Mittmann, M., Ho, M.-H., and Lockhart, D. J. 1997. Genome-wide expression monitoring in Saccharomyces cerevisiae. Nature Biotechnol. 15:1359-1367.

Yang, C., Katinakis, P., Hendriks, P., Smolders, A., De Vries, F., Spee, J., Van Kammen, A., Bisseling, T., and Franssen, H. 1993. Characterization of GmENOD40, a gene showing novel patterns of cell-specific expression during soybean nodule development. Plant J. 3:573-585.

Yang, C., Signer, E. R., and Hirsch, A. M. 1992. Nodules initiated by Rhizobium meliloti exopolysaccharide mutants lack a discrete, persistent nodule meristem. Plant Physiol. 98:143-151.

Zhu, J.-K., Shi, J., Bressan, R. A., and Hasegawa, P. M. 1993. Expression of an Atriplex nummularia gene encoding a protein homologous to the bacterial molecular chaperone DnaJ. Plant Cell 5:341-349. 